\title{
Investigation on potential groundwater impacts and influence of local hydrogeology on natural attenuation of leachate at a municipal landfill
}

\author{
${ }^{*}$ E. O. Longe, L. O. Enekwechi \\ Department of Civil and Environmental Engineering, University of Lagos, Akoka, Yaba, Lagos, Nigeria \\ Received 19 September 2006; revised 16 Novembert 2006; accepted 2 December 2006; available online 1 January 2007
}

\begin{abstract}
The influence of local hydrogeology on natural attenuation of contaminants from landfill leachates in shallow aquifer underlying the active Olusosun landfill base in Lagos was investigated. In addition, the level of groundwater contamination in the vicinity of the landfill and of leachate migration pattern in groundwater down gradient of the landfill base was equally assessed. Landfill leachate and groundwater samples were collected and analyzed and characterized. Physico-chemical analyses of sampled water followed standard analytical methods. Analytical results showed a measurable impact of leachate outflows on groundwater quality. Elevated levels of anions: nitrate, chloride and sulphate in the groundwater body and heavy metals: $\mathrm{Cr}_{3}, \mathrm{Cd}$ and $\mathrm{Cu}$, were detected at measurable levels in groundwater down gradient of the landfill location without any particular attenuation pattern. The migration pattern and dispersion of leachates down gradient, $750 \mathrm{~m}$ away from the landfill location are irregular and difficult to predict as depicted by levels of contaminants present in groundwater. The study highlighted the importance of soil stratigraphy beneath the landfill base as an important factor in the natural attenuation of leachate constituents in the groundwater body.
\end{abstract}

Key words: Landfill, natural attenuation, migration, leachate, hydrogeology

\section{INTRODUCTION}

Groundwater contamination is a major concern in landfill operations because of the pollutional effects of landfill leachates and its potential health risks (Lee, and Jones-Lee, 1993a; 1993b; Christensen, et al., 2001; Stollenwerk and Colman, 2003). The greatest contamination threat to groundwater comes from the leachate generated from the fill material which most often contains toxic substances especially when wastes of industrial origin are landfilled. However, it has been widely reported that leachates from landfills for nonhazardous waste could as well contain complex organic compounds, chlorinated hydrocarbons and metals at concentrations which pose a threat to both surface and ground waters. Solvents and other synthetic organic chemicals constitute a significant hazard, being of environmental significance at very low concentrations and resistant to degradation. Moreover, they may be transformed in some cases into more hazardous compounds (Baedecker, et al., 1979 and Christensen, et al., 2001). Most landfill leachate has high levels of BOD, COD, ammonia, chloride, sodium,

*Corresponding author, Email: dapolonge@yahoo.co.uk Tel./ Fax: +2341 4756429 potassium, hardness and boron. The conditions within a landfill often vary over time, from aerobic to anaerobic thus allowing different chemical reactions to take place. The leachate from landfills for non-hazardous waste could produce reducing conditions at landfill base thereby enhancing the percolation of iron and manganese solution from the underlying deposits. The chemical composition of leachate varies due to a number of different known factors as the age, type of waste, operational practices at the site and percolation rate through the fill to the groundwater. Heavy metals such as cadmium, arsenic, chromium have been reported at excessive levels in groundwater due to landfills operations (Lee, et al., 1986; Stollenwerk and Coleman, 2003). Bagchi (1989) described typical contaminants present in landfill leachate. Similarly, Lee and Jones (1993b) described typical composition of municipal landfill leachate. From the various studies over 40 organic compounds had been identified in leachate contaminated groundwater. Wood and Curran (1998) reported an average arsenic concentration in leachate contaminated groundwater to be as high as $21 \mu \mathrm{g} / \mathrm{L}$ with a range of 3.0-50 $\mu \mathrm{g} / \mathrm{L}$. An average arsenic concentration 
in the leachate plume as high as 326 $\mu \mathrm{g} / \mathrm{L}$ (range 52-647 $\mu \mathrm{g} / \mathrm{L}$ ) had also been reported (US Geological Survey, 2004). The volume of leachate depends principally on the area of the landfill, the meteorological and hydrogeological factors and effectiveness of capping. It is essential that the volume of leachate generated be kept to a minimum and also ensures that the ingress of groundwater and surface water is minimized and controlled. The volume of leachate generated is therefore expected to be very high in humid regions with high rainfall, or high run off and shallow water table (Chapman, 1992). This could well describe Lagos coastal environment where the topography is flat and low lying. The geology and hydrogeology of any potential landfill site thus have a major bearing on the level of natural protection for groundwater from contamination by landfill leachate. Even though there has been increasing concerns with regards to the vulnerability of groundwater to landfill operations in Lagos, Nigeria, there is however paucity of information as to the actual level of risk. Hence, there exists, a potential public health and environmental problems from existing solid waste management practices in Lagos State, the most critical being high risk to both surface water and groundwater quality through leachates outflow and infiltration (Lavalin, 1992; Longe and Kehinde, 2005). The main objective of this study was to investigate the influence of local hydrogeology on natural attenuation of contaminants from landfill leachates in shallow aquifer underlying the active Olusosun landfill base in Lagos. As part of the above overall stated objective, the determination of the level of groundwater contamination in the vicinity of the landfill and of leachate migration pattern in groundwater down gradient of the landfill base was assessed. The study was of a particular interest as groundwater is a major source for domestic and industrial water supply in the mega city (Longe, et al., 1987; Coode Blizard, 1997).

\section{MATERIALS AND METHODS}

Study area

The Olusosun landfill which is the focus of the current study occupies approximately 42 ha of land in Oregun, Ikeja Local Government Area, Lagos State. The active landfill area is made up of 37 hectares (Fig. 1). The site had been used in the past as a burrow pit where sand was mined for road construction. Initial excavation depth of 7 to 12 m existed before tipping of waste commenced. The landfill was designed to receive 7,365.000 tonnes of solid waste during its operational lifespan of $10 \mathrm{y}$. This Fig. represents a yearly average tipping volume of 736,500 tonnes. Operational design of waste to cover ratio of 9:1 was chosen for the ten years duration (Lavalin, 1992). The landfill accepts, officially, non-hazardous solid wastes of domestic, market, commercial, industrial and institutional origins but in practice all types of wastes are co-disposed. In order to ensure the integrity of the landfill under a natural attenuation design concept, a depth to seasonally high water table of 6metres from the landfill base was maintained. This is to allow for attenuation of leachate in the unsaturated zone. Its operation and maintenance were to be governed by stringent regulatory standards, but this has not been the case in practice.

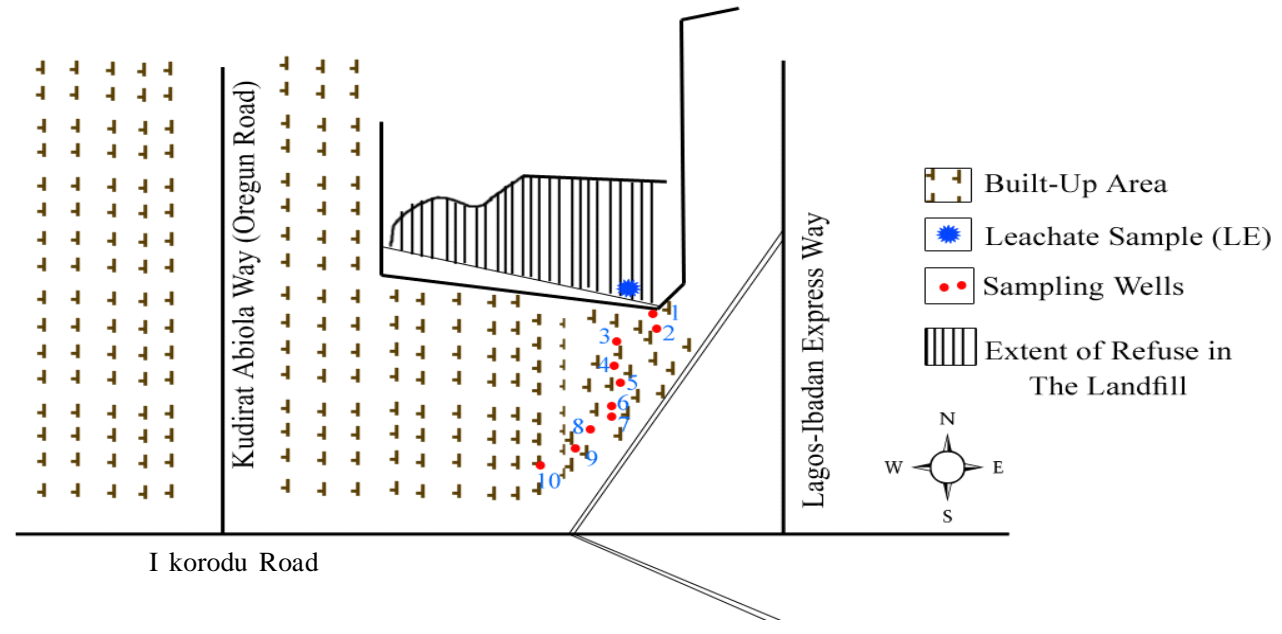

Fig. 1: A sketch diagram of the studied area with sampling points 
Field sampling and laboratory analysis

Sampling points have been designated W1 to W10 representing ten wells previously installed approximately between 20 and 750metres down gradient of the landfill location (Fig. 1). The ten water samples from the wells were used for this study. Groundwater sampling was carried out late July and early August 2004 during the raining season when a rise in water table was expected. A composite surface leachate sample scooped from the landfill base is designated LE. Both the leachate and groundwater samples were analyzed for parameters of interest characteristic to general mineral constituents in municipal landfill leachate such as total dissolved solids (TDS), chloride and heavy metals. The parameters were selected based on their relative importance in municipal landfill leachates composition, and their pollutional potential on groundwater resource in particular (Bagchi, 1989; Lee and Jones Lee, 1993b). Chloride was included in the groundwater quality assessment because of its measure of extent of dispersion of leachates in groundwater body (Chapman, 1992). All the sampled wells are protected sources of domestic water supply for private use. Each well was fitted with a surface pump. Groundwater samples were collected in plastic containers which were previously cleansed with nonionic detergent and finally rinsed with deionized water prior to usage. As part of the quality control measures, samples were rinsed with sampled groundwater before being filled. Samples for the measure of heavy metals were collected in $1.5 \mathrm{~L}$ polyethylene bottles and preserved using $2 \mathrm{~mL}$ concentrated $\mathrm{HNO}_{3}$ acid. All samples were preserved at $4^{\circ} \mathrm{C}$ and transported to the laboratory for analysis. Physico-chemical analyses of sampled water followed standard analytical methods. The $\mathrm{pH}$ was determined in-situ while the TDS was determined using a Horiba U-10 multiprobe meter. The dissolved oxygen level was measured using the Winkler's method. Levels of nitrate, phosphate, $\mathrm{NH}_{3}$ $\mathrm{N}$, and sulphate were determined using $\mathrm{UV} /$ visible spectrophotometer, wavelength $200-1000 \mathrm{~mm}$, and chloride was determined by silver nitrate titration. Levels of heavy metals of interest, cadmium, copper, lead, chromium, iron, manganese and zinc were measured using Atomic Absorption Spectrometer with flame, graphite furnace and hydride system. The necessary hydrogeological study consisted of collation and analysis of existing hydrogeological data on strata logs, groundwater levels; and flow direction. Rainfall data for over a period of 20 years from the nearest metrological station to the study area was collected and analyzed.

\section{RESULTS}

\section{Geohydrological conditions}

A major river, the Ogun is about $1 \mathrm{~km}$ away north of the landfill location and it drains approximately 2,500 hectares of land. It flows in a southeasterly direction. The climate of the landfill location is consistent with the general climatic characteristics of the coastal environment in general and metropolitan Lagos in particular. There exists two principal climatic seasons, the rainy (wet) and dry seasons.

The wet season is from the month of April through October with a short break in mid-August, while the dry season is from the month of November through March. From the rainfall data analysis, the mean annual precipitation of the area is $1,526 \mathrm{~mm}$ which is lower than that of the entire Lagos metropolis of $3000 \mathrm{~mm} /$ year. This drier climate than what is generally obtainable in Lagos is expected to influence the volume of leachates production at the landfill site. Total monthly rainfall of greater than $175 \mathrm{~mm}$ characterized the months of May through Mid-August, while in June a monthly rate of $294 \mathrm{~mm}$ on average have been recorded. Fig. 2 presents mean precipitation from the landfill site for a ten year period. Recorded total monthly rainfall values for the months of September and October are 194 and $172 \mathrm{~mm}$ respectively with a decline as the dry season sets in gradually. Between the dry season months of November and March, recorded total monthly rainfall is low, values range between $28.5 \mathrm{~mm}$ and $100.0 \mathrm{~mm}$ while a monthly average of less than $20 \mathrm{~mm}$ characterized the month of January. An estimated mean annual potential evapo-transpiration of the landfill site had been evaluated as $98 \mathrm{~cm}$ (Lavalin, 1999).

\section{Hydrogeology}

The hydrogeological condition of the landfill site is consistent with the regional hydrogeological setting of Lagos area as depicted by Longe, et al., (1987). The sub-surface geology of the landfill reveals a lateritic cover, reddish brown in colour with sand and clay portions. The lateritic cover is of variable thickness averaging 4metres. This lateritic cover overlies an alternating sequence of sand and clay deposit (Fig. 3). Underlying this is a water-bearing zone consisting of loose, medium to coarse sand with an average thickness of $10.4 \mathrm{~m}$. 


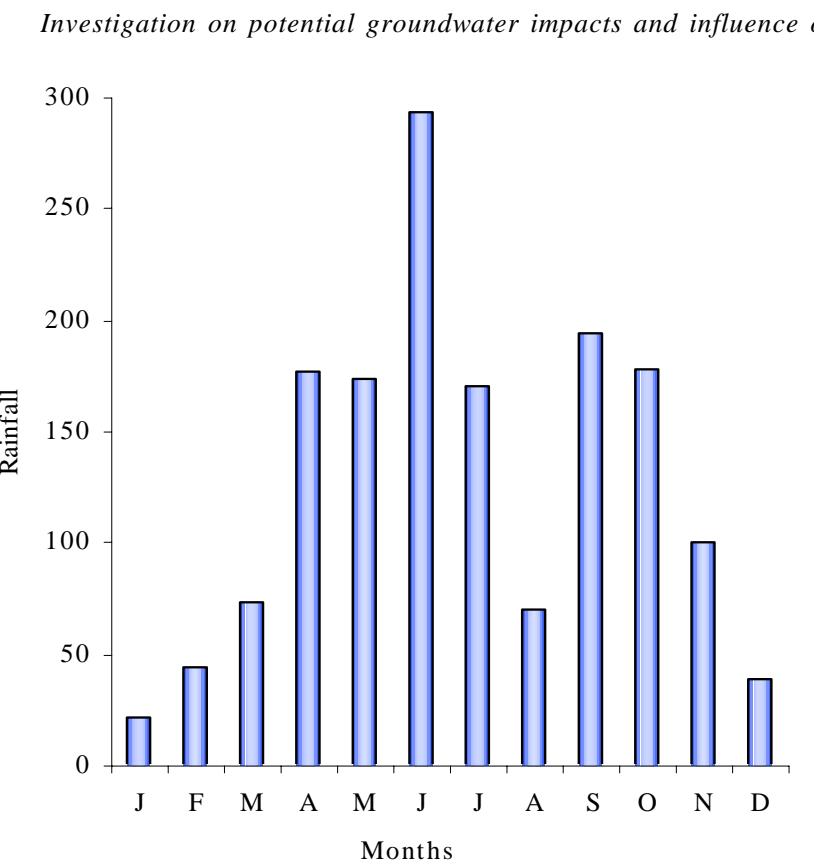

Fig. 2: Average rainfall in Ikeja area of Metropolitan Lagos

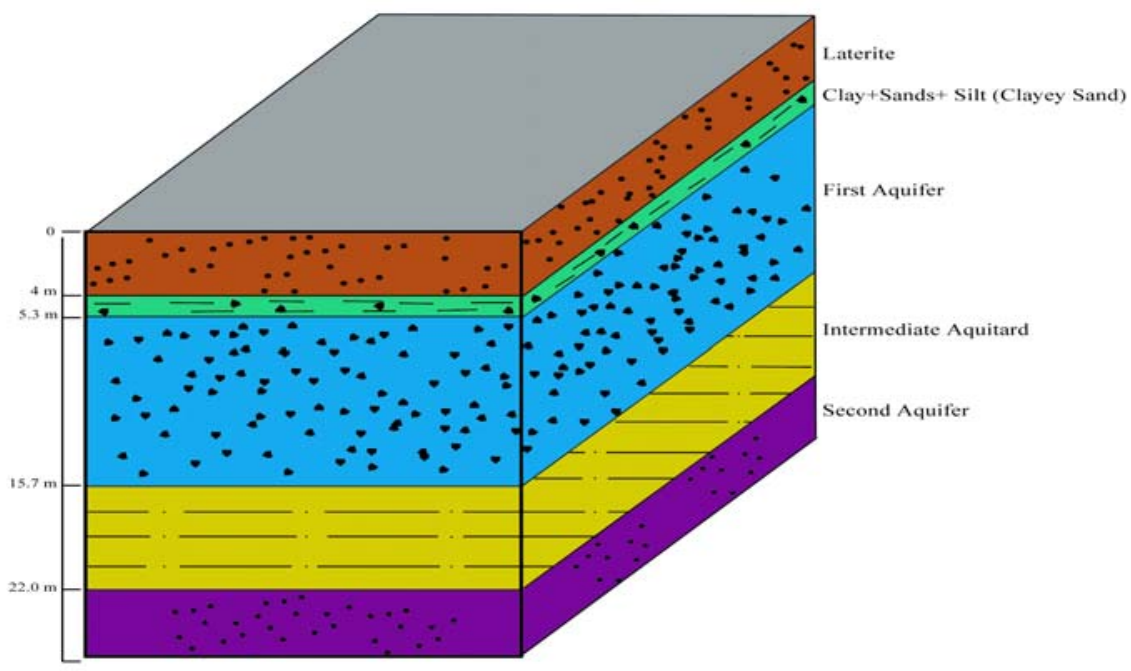

Fig. 3: A schematic block diagram of subsurface geology of the landfill location

Depths of occurrence vary from 4 to $7 \mathrm{~m}$ at the northern part of the landfill to $10 \mathrm{~m}$ at the southern end. This represents the first aquifer horizon described by Longe, et al., (1987). The aquifer has a predominant lateral groundwater movement and it is prone to contamination. The calculated hydraulic conductivity of this water-bearing zone is in the order of $10^{-3} \mathrm{~cm} / \mathrm{s}$. This aquifer horizon is immediately underlain by a semipermeable layer of reddish gray, silt with clay seal of variable thickness averaging at $4 \mathrm{~m}$. Hazen estimates from grain size analysis, indicates hydraulic conductivity of $10^{-7} \mathrm{~cm} / \mathrm{s}$ for the semi-permeable layer that separates the first aquifer from the underlying aquifer horizon. The second aquifer consists of medium sand with traces of silt and exhibits hydraulic conductivities of the order of $10^{-4}$ to $10^{-3} \mathrm{~cm} / \mathrm{s}$. The first and second aquifer horizons are major sources of domestic and industrial water supply and both are the main thrust of this work. 


\section{Groundwater quality}

Analytical results of physico-chemical characteristics of leachates and groundwater samples from wells are presented in Tables 1 to 4 . The groundwater is generally acidic with $\mathrm{pH}$ values varying between 3.90 and 5.27, while the leachate is slightly neutral. The mean $\mathrm{pH}$ value of 4.66 recorded for the groundwater in this study is below the stipulated $\mathrm{WHO} \mathrm{pH}$ tolerance range of 6.5 to 8.6 for potable water (WHO, 2004). Water from W8 at 600 metres away from the landfill has the lowest $\mathrm{pH}$ of 3.9 , hence the most acidic in this present study. The total dissolved solids (TDS) values obtained in groundwater varied from 201 to $800 \mathrm{mg} / \mathrm{L}$, while the TDS value obtained for the leachate was $3,215 \mathrm{mg} / \mathrm{L}$. A significant attenuation of TDS concentrations in all wells could be observed down gradient of the landfill site but without any particular pattern.

Table 1: Physico-chemical characteristics of leachate and groundwater

\begin{tabular}{|c|c|c|c|c|c|c|c|c|c|}
\hline Sample & Distance (m) & $\mathrm{pH}$ & $\begin{array}{l}\text { TDS } \\
(\mathrm{mg} / \mathrm{L})\end{array}$ & $\begin{array}{l}\mathrm{Ca} \\
(\mathrm{mg} / \mathrm{L})\end{array}$ & $\begin{array}{l}\mathrm{NH}_{4}^{+} \\
(\mathrm{mg} / \mathrm{L})\end{array}$ & $\begin{array}{l}\mathrm{SO}_{4} \\
(\mathrm{mg} / \mathrm{L})\end{array}$ & $\begin{array}{l}\mathrm{NO}_{3} \\
(\mathrm{mg} / \mathrm{L})\end{array}$ & $\begin{array}{l}\mathrm{Cl}^{-} \\
(\mathrm{mg} / \mathrm{L})\end{array}$ & $\begin{array}{l}\mathrm{PO}_{4}^{-} \\
(\mathrm{mg} / \mathrm{L}) \\
\end{array}$ \\
\hline $\mathrm{LE}$ & 0 & 7.36 & 3215 & 1460 & 1.50 & 25 & 2.5 & 1000 & 3.5 \\
\hline W 1 & 20 & 4.50 & 241.5 & 105.9 & 0.15 & 25.15 & 0.12 & 75.47 & 0.21 \\
\hline W 2 & 50 & 5.03 & 259.0 & 237.3 & 0.16 & 26.76 & 0.21 & 80.50 & 0.04 \\
\hline W 3 & 400 & 4.22 & 201.0 & 168.0 & 0.16 & 20.88 & 0.21 & 62.66 & 0.01 \\
\hline W4 & 450 & 4.69 & 214.0 & 113.2 & 0.14 & 22.34 & 0.31 & 67.03 & 0.03 \\
\hline W5 & 500 & 5.27 & 289.5 & 262.8 & 0.18 & 30.15 & 0.12 & 90.46 & 0.01 \\
\hline W6 & 550 & 4.77 & 250.0 & 219.0 & 0.16 & 26.09 & 0.21 & 78.28 & 0.05 \\
\hline W7 & 560 & 4.06 & 292.0 & 109.5 & 0.19 & 30.42 & 0.32 & 91.25 & 0.03 \\
\hline W8 & 600 & 3.90 & 615.0 & 146.0 & 0.38 & 64.00 & 0.21 & 192.0 & 0.02 \\
\hline W 9 & 650 & 5.06 & 800.0 & 277.4 & 0.50 & 80.33 & 0.43 & 250.0 & 0.05 \\
\hline W10 & 750 & 5.14 & 272.5 & 292.0 & 0.17 & 28.39 & 0.22 & 85.16 & 0.03 \\
\hline WHO STD & & $6.5-8.5$ & 500 & 200 & 0.5 & 400 & 10 & 250 & 5.0 \\
\hline
\end{tabular}

Table 2: Descriptive statistics for physico-chemical parameters of leachate and groundwater

\begin{tabular}{lllllllll}
\hline Parameter & Min & Max & Mean & SD & SE & Variance & Median & Range \\
\hline pH & 3.90 & 5.27 & 4.66 & 0.48 & 0.15 & 0.23 & 4.73 \\
TDS & 201.00 & 800.00 & 343.45 & 198.91 & 0.15 & 39564.08 & 265.75 \\
$\mathrm{Ca}^{+}$ & 105.90 & 292.00 & 193.11 & 73.18 & 23.14 & 5355.05 & 193.50 \\
$\mathrm{NH}_{4}^{+}$ & 0.14 & 0.50 & 0.22 & 0.12 & 0.038 & 0.01 & 292.00 & 0.16 \\
$\mathrm{SO}_{4}^{+}$ & 20.88 & 80.33 & 35.45 & 19.96 & 6.31 & 398.43 & 27.58 & 5.36 \\
$\mathrm{NO}_{3}^{-}$ & 0.12 & 0.43 & 0.24 & 0.09 & 0.03 & 0.01 & 0.12 \\
$\mathrm{Cl}^{-}$ & 62.66 & 250.00 & 107.28 & 62.14 & 19.65 & 3861.86 & 82.83 \\
$\mathrm{PO}_{4}^{+}$ & 0.01 & 0.21 & 0.05 & 0.06 & 0.02 & 0.003 & 0.31 \\
\hline
\end{tabular}

Calcium concentrations in the groundwater varied between 105.9 and $292.0 \mathrm{mg} / \mathrm{L}$. A mean value of 193.1 $\mathrm{mg} / \mathrm{L}$ was obtained which fell below the WHO stipulated tolerance level of $200 \mathrm{mg} / \mathrm{L}$ for potable water. However water from five out of the ten wells tested: $\mathrm{w}_{2}, \mathrm{w}_{5}, \mathrm{w}_{6}, \mathrm{w}_{9}$ and $\mathrm{w}_{10}$ had values far above the WHO stipulated tolerance level. The presence of calcium in water generally varies according to the proximity of natural sources. Sewage and industrial wastes are known to account for such anthropogenic sources of calcium in water. The measured values of ammonia, sulphate, nitrate and phosphate in leachate sample and in groundwater were below the WHO stipulated value for each of the anion for potable water (Table 2). The exception in this observation is the concentration of $\mathrm{NH}_{4}^{+}$; the leachate has an elevated value of $1.50 \mathrm{mg} / \mathrm{L}$, while the concentrations in the groundwater ranged from 0.14 to $0.50 \mathrm{mg} / \mathrm{L}$. The presence of $\mathrm{NH}_{4}^{+}$in groundwater has biochemical significance as a useful indicator of organic pollution (Chapman, 1992). Measured chloride concentration in leachate was $1000 \mathrm{mg} / \mathrm{L}$ while its concentration in groundwater ranged between 62.66 and $250.0 \mathrm{mg} / \mathrm{L}$. There was no definite attenuation pattern observed in wells down gradient of the landfill site. Chloride is a good measure of the extent of the dispersion of leachates in groundwater. However, high chloride concentrations are yet common in groundwater in Lagos but, an increasing chloride concentrations in the coastal groundwater have been reported (Coode Blizard, 1997). The current observed chloride concentration in groundwater samples are above the background chloride levels in aquifer underlying Lagos metropolis. 
The heavy metals

Measured values of heavy metals in landfill leachate and groundwater are presented in Table 3, while Table 4 presents the descriptive statistics of the heavy metals. The trace metals rarely occur in groundwater at concentrations large enough to comprise a significant percentage of the total dissolved solids. Except for iron, heavy metals in natural or contaminated groundwater almost invariably occur at concentrations below $1 \mathrm{mg} / \mathrm{L}$ (Chapman, 1992). The measured values of Fe, Mn and $\mathrm{Pb}^{+}$in the landfill leachate were above the WHO tolerance levels for drinking water quality. High iron
Lead $\left(\mathrm{Pb}^{+}\right)$was not detected in any of the well. Its non detection in groundwater may not be unconnected with its affinity to be absorbed by clayey soils. Zinc and chromium were not detected in the landfill leachate but were found in appreciable levels in the groundwater. Measured values of $\mathrm{Zn}$ ranged from 0.01 to $0.40 \mathrm{mg} / \mathrm{L}$, a mean value of $0.17 \mathrm{mg} / \mathrm{L}$, which is far below the WHO tolerance value of $5.0 \mathrm{mg} / \mathrm{L}$ specified for potable water was obtained. However, high levels of chromium were measured in all wells. The mean value of $0.89 \mathrm{mg} / \mathrm{L}$ (range $0.02-1.71 \mathrm{mg} / \mathrm{L}$ ) is far above the WHO acceptable level of $0.05 \mathrm{mg} / \mathrm{L}$.

Table 3: Heavy metals concentrations in leachate and groundwater

\begin{tabular}{|c|c|c|c|c|c|c|c|c|}
\hline Samples & $\begin{array}{l}\text { Distance } \\
(\mathrm{m})\end{array}$ & $\begin{array}{l}\mathrm{Fe} \\
(\mathrm{mg} / \mathrm{L})\end{array}$ & $\begin{array}{l}\mathrm{Mn} \\
(\mathrm{mg} / \mathrm{L})\end{array}$ & $\begin{array}{l}\mathrm{Cu} \\
(\mathrm{mg} / \mathrm{L})\end{array}$ & $\begin{array}{l}\mathrm{Zn} \\
(\mathrm{mg} / \mathrm{L})\end{array}$ & $\begin{array}{l}\mathrm{Pb} \\
(\mathrm{mg} / \mathrm{L})\end{array}$ & $\begin{array}{l}\mathrm{Cr}^{3} \\
(\mathrm{mg} / \mathrm{L})\end{array}$ & $\begin{array}{l}\mathrm{Cd} \\
(\mathrm{mg} / \mathrm{L})\end{array}$ \\
\hline LE & 0 & 1.056 & 0.35 & ND & ND & 0.113 & ND & ND \\
\hline W1 & 20 & 0.41 & 0.08 & 0.35 & 1.75 & ND & 1.13 & ND \\
\hline W2 & 50 & 0.64 & 0.13 & 0.05 & 0.25 & ND & 0.30 & ND \\
\hline W3 & 400 & 0.52 & 0.10 & 0.01 & 0.05 & ND & 0.95 & ND \\
\hline W4 & 450 & 0.51 & 0.10 & 0.31 & 1.55 & ND & 0.74 & ND \\
\hline W5 & 500 & 1.11 & 0.22 & 0.40 & 2.00 & ND & 0.85 & ND \\
\hline W6 & 550 & 0.60 & 0.13 & 0.17 & 0.85 & ND & 0.20 & ND \\
\hline W7 & 570 & 0.40 & 0.08 & 0.08 & 0.40 & ND & 1.67 & ND \\
\hline W8 & 600 & 0.82 & 0.16 & 0.03 & 0.15 & ND & 0.34 & ND \\
\hline W9 & 650 & 4.19 & 0.84 & 0.35 & 1.75 & ND & 1.71 & ND \\
\hline W10 & 750 & 0.44 & 0.09 & 0.02 & 0.10 & ND & 1.02 & ND \\
\hline WHO & & 0.3 & 0.1 & 1.0 & 5.0 & 0.05 & 0.05 & 0.01 \\
\hline
\end{tabular}

ND $=$ Not detected

Table 4: Descriptive Statistics for heavy metals in groundwater

\begin{tabular}{lllllllll}
\hline Parameter & Min & Max & Mean & SD & SE & Variance & Median & Range \\
\hline $\mathrm{Fe}$ & 0.4 & 4.19 & 0.96 & 1.15 & 0.37 & 1.33 & 0.56 & 3.79 \\
$\mathrm{Mn}$ & 0.08 & 0.84 & 0.19 & 0.23 & 0.07 & 0.05 & 0.11 & 0.76 \\
$\mathrm{Cu}$ & 0.01 & 0.40 & 0.17 & 0.16 & 0.05 & 0.02 & 0.12 \\
$\mathrm{Zn}$ & 0.01 & 0.40 & 0.17 & 0.16 & 0.05 & 0.02 & 0.12 \\
$\mathrm{~Pb}$ & 0.00 & 0.00 & 0.00 & 0.00 & 0.16 & 0.02 & 0.12 \\
$\mathrm{Cr}$ & 0.20 & 1.71 & 0.89 & 0.53 & 0.16 & 0.28 & 0.39 \\
\hline
\end{tabular}

concentrations were measured in groundwater with no discernable attenuation trend down gradient of the landfill site. However, high iron concentrations in groundwater have been widely reported in the country (WHO/UNICEF, 2006). Measured values of iron in groundwater ranged from 0.41 to $4.19 \mathrm{mg} / \mathrm{L}$, the mean value of 0.94 exceeded the WHO tolerance level of 0.30 $\mathrm{mg} / \mathrm{L}$ for potable water, thereby making iron an important groundwater quality issue in the study area. Concentrations of manganese in all the wells ranged between 0.08 and $0.84 \mathrm{mg} / \mathrm{L}$ with a mean value of 0.193 $\mathrm{mg} / \mathrm{L}$. Concentrations of manganese in excess of 0.2 $\mathrm{mg} / \mathrm{L}$ makes water distasteful to drink with no specific toxic effects. An acceptable level of $0.05 \mathrm{mg} / \mathrm{L}$ set by WHO for drinking water quality was not met by the groundwater quality. Heavy doses of chromium salts even though are rapidly eliminated from human body, could corrode the intestinal tract (WHO, 2004). Levels of copper $\left(\mathrm{Cu}^{2+}\right)$ measured in groundwater ranged between 0.01 and $0.40 \mathrm{mg} / \mathrm{L}$ less than the WHO specified tolerance level of $1.0 \mathrm{mg} / \mathrm{L}$ for drinking water quality.

\section{DISCUSSION AND CONCLUSION}

The general acidic nature of groundwater is could not be solely attributed to leachate contamination. High iron level is characteristic of groundwater quality in Nigeria in general and in Lagos in particular (WHO/ UNICEF, 2006). For the anions, there is no definite attenuation pattern observed in wells down gradient 
of the landfill site. For instance, the observed TDS concentrations of 615 and $800 \mathrm{~g} / \mathrm{L}$ obtained in wells W8 and W9 respectively at distances of 600 and 670 $\mathrm{mL}$ corroborates this observation. Aside from these two wells, the TDS values of water from all the other wells fell below the WHO tolerance level of $500 \mathrm{mg} / \mathrm{L}$ for drinking water quality. Nearly all trace metals of interest in groundwater problems are influenced by redox conditions, as a result of either of changes in the oxidation state of the trace metal or non-metallic elements with which it forms complexes. The groundwater often acts as a redox environment due to changes in solid phases in the porous medium with adsorption of the trace metal. This may partly be responsible for the occurrence of trace metals at low concentrations in the groundwater samples. The presence of $\mathrm{Pb}^{+}$in the landfill leachate and its absence in all the wells down gradient of the landfill is best explained by the presence of clayey soil. The mobility of $\mathrm{Pb}^{+}$in clayey materials is low. In soil systems, $\mathrm{Pb}^{+}$ can also form poorly soluble precipitates with sulphate, carbonate, phosphate and sulphide anions. In a municipal landfill, where anaerobic conditions are likely to occur, $\mathrm{Pb}^{+}$should become more mobile, but this is not so in this case. Even though the soil material that favours its attenuation in leachate includes organic matter, clays, and free lime, the only possible contributing factor here is clay. The sub-soil stratigraphy of the study area which is characterized with the presence of an unsaturated zone of about $6 \mathrm{~m}$ above the water table is expected to equally play a major role. The unsaturated zone which consists of silty clay could as well play a significant role in the natural attenuation of leachate in groundwater body. The observed attenuation pattern of contaminants in wells up to the distance of $750 \mathrm{~m}$ away from the landfill site is irregular and unpredictable. The local geology of the study area appears to play a major role in this respect. The noticeable stratigraphic variations depicting the local geology (Fig. 3) may have influenced natural attenuation of contaminants, their pattern of transfer and subsequent breakthrough into the groundwater body. Heterogeneities are of significant importance in the aquifers underlying Lagos metropolis (Longe, et al., 1987), hydraulic conductivity contrasts do occur, due to intercalations of semipermeable and impermeable layers. This existing hydrogeological setting favours adsorption and retention of contaminants in the pore spaces, thereby making pattern of leachate dispersion very irregular and difficult to predict. As much as some of the contaminants are found in groundwater at concentrations higher than the background groundwater chemistry of aquifer in Lagos, there is therefore the tendency to suspect the landfill as one of the sources of groundwater contamination in the study area. The study has highlighted the importance of soil stratigraphy beneath the landfill base as an important factor in the attenuation of leachate constituents. The local hydrogeological setting might have contributed to the enhancement of the natural attenuation of contaminants to a certain degree. However, impairment of groundwater quality is not totally removed or eliminated. There is a great tendency for an increase in groundwater contamination around the landfill location considering the current levels of chloride, nitrate and organics found in the groundwater which are above background levels. In order to complement this preliminary result, further study on groundwater quality in and around the landfill in all directions other than in one as presently carried out will be necessary. This is to further ascertain the suitability or otherwise of the natural attenuation landfill type, and confirm the efficiency of the influence of the local sub-soil stratigraphy as well as the hydrogeology in groundwater protection from leachate outflows at the landfill site. This becomes very important as confirmatory result could promote natural attenuation type landfill as an alternative to the expensive containment and engineered landfill in developing nations of the world where financial resources are limited and technical or managerial capability to operate such facility are lacking. This could then guarantee a reduction in groundwater contamination resulting from unplanned municipal solid waste management. In addition to the above, in the interim, in order to protect the groundwater quality of the study area, a monitoring programme for groundwater quality status around the vicinity of the landfill is suggested. Monitoring wells should be sited both in the up gradient and down gradient of the landfill. Groundwater monitoring wells of 10 to $15 \mathrm{~m}$ intervals should be sited along the down gradient perimeters, southeasterly and western edges of the landfill. At least two number wells should be sited at approximately 5 to $10 \mathrm{~m}$ intervals along the up gradient in the perimeters, $\mathrm{N}-\mathrm{W}$ edges of the landfill to monitor background water quality. Finally, for sitting new landfills, the potential for pollution of 
groundwaters could be drastically minimized by maintaining an adequate buffer zone between the landfill and the property line of the adjacent property. A buffer zone of three miles in the direction of groundwater flow is most appropriate (Lee et al., 2005).

\section{ACKNOWLEDGEMENT}

The authors thank the Ministry of the Environment, Lagos State for allowing this research to be carried out at the Olusosun landfill and for the valuable and useful information made available to the researchers.

\section{REFERENCES}

Baedecker, M.J., Back, W., (1979). Hydrogeological processes and chemical reactions at a landfill: Ground Wat., 17, 429437.

Bagchi, A., (1989). Design, construction and monitoring of sanitary landfill. John Wiley \& Sons, New York.

Chapman, D., (1992). Water quality assessments. A guide to the use of biota, sediments and water in environmental monitoring. UNESCO/WHO/UNEP, Chapman \& Hall, London, 371-460.

Coode B., (1997). Hydrogeological investigation of Lagos State. Final report, volume 1 submitted to Lagos State Water Corporation.

Christensen, T.H., Kjeldsen, P., Bjerg, P.L., Jensen, D.L., Christensen, J.B., Baun, A., Albrechtsen, H.J., Heron, G., (2001). Biogeochemistry of landfill leachate plumes: Appl. Geochem., 16, 659-718.

Lavalin., (1992). Organizational development and waste management system project. Design and operations report for the Oregun landfill site submitted to the Lagos State Waste Disposal Board.

Lee, G.F., Jones, R.A., Ray, C., (1986). Sanitary landfill leachate recycle. Biocycle, 27, 36-38.
Lee, G.F., Jones-Lee, A., (1993a). Revisions of state of MSW landfill regulations: Issues in groundwater quality. J. Environ. Manag. Rev., 29, 32-54.

Lee, G.F., Jones-Lee, A., (1993b). Groundwater pollution by municipal landfills: Leachate composition, detection and water quality significance," Proc. Sardinia '93 IV International Landfill Symposium, Sardinia, Italy, 10931103. Available at: http://www.waterencyclopedia.com/La$\mathrm{Mi} /$ Landfills-Impact-on-Groundwater.html

Lee, G.F., Jones Lee, A., (2005). Public health, groundwater resource and environmental protection from MSW leachate pollution by single and double composite lined dry tomb landfills. Available at: http://www.members.aol.com/annejlee/ Double-compLF-Pro.pdf

Longe, E.O., Malomo, S., Olorunniwo, M.A., (1987). Hydrogeology of Lagos metropolis, J. African Earth Sci., 6 (3), 163-174.

Longe, E.O., Kehinde M.O., (2005). Investigation of potential groundwater impacts at an unlined waste disposal site in

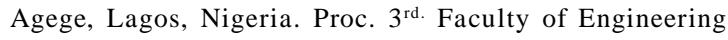
International Conference, University of Lagos, Lagos, 2129.

Stollenwerk, K.G., Colman, J.A., (2003). Natural remediation potential of arsenic-contaminated ground water, in Welch, A.H., and Stollenwerk, K.G., Eds., Arsenic in ground waterGeochemistry and occurrence, Boston, Kluwer, 351-379.

US Geological Survey., (2004). Natural remediation of arsenic contaminated groundwater associated with landfill leachate. Fact Sheet 2004-3057. Avaiable at: http://pubs.water.usgs.gov/ fs/2004-3057/

World Health Organization (WHO), (2004). Guidelines for

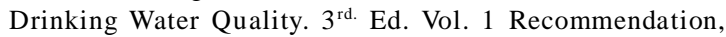
Geneva, 515.

World Health Organization (WHO) and UNICEF., (2006). Rapid Assessment of Drinking Water Quality. Country Report, Nigeria, 82.

Woodard, Curran. (1998). Final remedial investigation report of Saco Municipal Landfill Superfund Site, Saco, Maine: Portland, Maine, Woodard and Curran, Inc., 180.

\section{AUTHOR (S) BIOSKETCHES}

Longe, E.O., Ph.D., Department of Civil and Environmental Engineering, University of Lagos, Akoka, Yaba, Lagos, Nigeria. Email: dapolonge@yahoo.co.uk

Enekwechi, L.O., B.Sc., M.Sc., Graduate Student, Department of Civil and Environmental Engineering

University of Lagos, Akoka, Yaba, Lagos, Nigeria. Email: epslconsult@yahoo.com

This article should be referenced as follows:

Longe, E.O., Enekwechi, L.O., (2007). Investigation on potential groundwater impacts and influence of local hydrogeology on natural attenuation of leachate at a municipal landfill. Int. J. Environ. Sci. Tech., 4 (1), 133140. 